\title{
CLINICAL AND LABORATORY EVALUATION OF MEASLESLIKE RASH IN CHILDREN AND YOUNG ADULTS
}

\author{
Klaus Eberhard Stewien ${ }^{1}$; Lourdes Rehder de Andrade Vaz de Lima²; Viviane Fongaro Botosso ${ }^{3}$; \\ Maria Isabel de Oliveira ${ }^{2}$; Simone N. Fagundes ${ }^{1}$; Meri B. Nogueira ${ }^{4}$; Selma Lopes Betta Ragazzi ${ }^{5}$; \\ Maria Tereza Zuluni da Costa ${ }^{5}$; Bernardo Ejzenberg'; Edison Luiz Durigon ${ }^{1 *}$
}

\begin{abstract}
${ }^{1}$ Departamento de Microbiologia, Instituto de Ciências Biomédicas, Universidade de São Paulo, São Paulo, SP, Brasil. ${ }^{2}$ Seção de Imunologia e Seção de Virologia do Instituto Adolfo Lutz, São Paulo, SP, Brasil. ${ }^{3}$ Serviço de Virologia, Instituto Butantan, São Paulo, SP, Brasil. ${ }^{4}$ Laboratorio de Virologia do Hospital das Clínicas, Universidade Federal do Paraná, Curitiba, PR, Brasil. ${ }^{5}$ Hospital Universitário da Universidade de São Paulo, Cidade Universitária, São Paulo, SP, Brasil
\end{abstract}

Submitted: February 17, 2000; Returned to authors for corrections: May 08, 2000; Approved: November 13, 2000

\begin{abstract}
A clinical and laboratory evaluation of 11 children and young adults with measleslike rash was done during the measles outbreak in the Greater São Paulo Metropolitan area at the end of 1996 and spread over the country during 1997. Measles was laboratory confirmed in 07 patients by specific IgM detection in acute serum specimens using an IgM-capture EIA, by specific IgG seroconversion in serum pairs, and by reverse transcription PCR and virus isolation in peripheral blood lymphocytes. Clinical presentations were not always classic; one of the 07 cases had received measles vaccine and corresponded to modified clinical case of measles. The 4 remaining cases were negative for measles and were diagnosed as exanthem subitum ( 2 cases), scarlet fever and Kawasaki disease. The present study reinforces the view that clinical features alone are not sufficient for establishing an accurate diagnosis in the post-vaccine era, and a surveillance system based on sensitive laboratory results is needed so that it can confirm IgM-negative measles cases.
\end{abstract}

Key words: measles, clinical evaluation, laboratory investigation, polymerase chain reaction, measles virus isolation, enzyme immunoassay

\section{INTRODUCTION}

Measles remains one of the leading causes of morbidity and mortality in children $<5$ years of age in developing countries $(9,12)$. The World Health Organization estimates that more than 1 million people die from measles and its complications in these countries every year (25). In the Americas, experience in the past 5 years suggests that measles transmission has been interrupted and the disease successfully controlled by intensive vaccination programs (19). While vaccine coverage against the disease has been maintained in the past five years, significant measles outbreaks have continued to occur in American countries (1). In Brazil, an epidemic began in the Greater São Paulo Metropolitan area at the end 1996 and spread over the country during 1997 (18).
The measles virus is highly contagious and causes a disease characterized by high fever, cough, coryza, conjunctivitis and a maculopapular rash. Since measles is often followed by immunossupression, secondary bacterial infections are common, leading mostly to pneumonia, diarrhea and otitis (9). In developing countries, fatality rates for measles can reach $10 \%$ in malnourished populations (22).

While reaching the goal of global eradication of measles will require continued efforts to increase vaccination coverage levels, a sensitive surveillance system is fundamental for a measles elimination program $(17,19)$. Virological laboratories will play a critical role in monitoring the success of measles control strategies by timely investigation of suspected measles cases. Laboratory sequencing of the viral genome from measles isolates can also help to determine geographic

\footnotetext{
* Corresponding author. Mailing address: Departamento de Microbiologia, ICB II - USP, Av. Prof. Lineu Prestes, 1374, Cidade Universitária, CEP 05508-900, São Paulo, SP, Brasil. Fax: (+5511) 3813-7354. E-mail: eldurigo@icb.usp.br
} 
sources of outbreaks and identify pathways of transmission $(2,20)$.

The World Health Organization has identified effective case management as one of the specific strategies for reducing the burden of the disease $(12,25)$. However, the clinical diagnosis of measles can be difficult, making surveillance more complicated than was the case for poliomyelitis or smallpox. After introduction of the measles vaccine, atypical and modified disease cases were frequently observed, mostly in young infants, malnourished children and previously immunized individuals $(8,9)$. A number of exanthems, due to other viruses and bacteria, adverse drug reactions and other causes, can be easily confused with measles and need laboratory confirmation $(6,15)$.

Laboratory diagnostic procedures consist of the classical virus isolation (1), direct detection of the virus or viral antigens in secretions (2) and detection of specific antibodies by serological methods $(3,9)$. In this work we evaluate clinical and laboratory investigation data from children, and young adults with measleslike rash, using virus isolation and identification techniques, direct viral genome detection by polymerase chain reaction (PCR) and specific $\mathrm{IgM}$ and $\mathrm{IgG}$ antibody detection by enzyme immunoassay (EIA).

\section{MATERIALS AND METHODS}

Patient selection. Patients with an erythematous maculopapular exanthem, attending the University Hospital, University of São Paulo, were eligible for inclusion in the study. The hospital serves mostly low income children and adults residing in the Butantan health district (ERSA-2), which has a population of $\sim 250,000$. The diagnosis and clinical features were recorded by a doctor, and clinical specimens were taken from each patient. The Health Ministry of Brazil clinical case definition criteria was used for classifying typical definition and modified illnesses $(6,9)$. All specimens were transported on the same day to the Laboratories of Clinical and Molecular Virology of the Department of Microbiology, Institute of Biomedical Sciences, University of São Paulo, where the virologic and serologic investigations were done.

\section{Virologic and serologic studies}

Clinical specimens. Peripheral blood lymphocytes were obtained from heparinized blood by centrifugation through onethird volume of Fycoll-Hypaque (Sigma, St. Louis, MO, USA) at $1000 \mathrm{xg}$ for $45 \mathrm{~min}$ at room temperature. Lymphocytes at the interface were aspirated and washed three times with Hanks' BSS-containing antibiotics before being resuspended in a small volume of BSS. Midstream urine was collected in a sterile container, centrifuged at $800 \mathrm{xg}$ for $30 \mathrm{~min}$. Sediments were resuspended in 1-2 $\mathrm{ml}$ of Hanks' BSS for viral isolation and reverse transcription PCR. Blood samples to be used for serological analysis were also taken from each patient.
Measles virus isolation. Lymphocyte suspensions of $0.5 \mathrm{ml}$ were innoculated into monolayer cultures of B95a cells grown in $25 \mathrm{ml}$ culture flasks, according to Kobune et al. (13). Cell cultures were incubated at $37^{\circ} \mathrm{C}$ in a $\mathrm{CO}_{2}$-incubator and examined every day for a cytopathic effect (CPE) characterized by syncytium formation. Cells from positive cultures were scraped into fresh medium, and cell extract was prepared by freezing and thawing. Extracts were placed into Vero monolayers and identified by indirect immunofluorescence assay (IFA) (16), using monoclonal antibodies kindly supplied by Chemicon International, Inc., Temecula, Calif., USA.

Reverse transcription PCR and "nested" PCR. Measles virus genomic RNA was detected in peripheric blood lymphocytes and in urine sediment by reverse transcription and amplification by PCR, using primers targeted to the highly conserved region of the $\mathrm{N}$ gene, according to Rota et al. (21). Primers were kindly supplied by Dr. William J. Bellini (Centers for Disease Control and Prevention, Atlanta, GA, USA). Human herpesvirus 6 DNA was detected in the peripheral blood lymphocytes by "nested" PCR, as previously described by Kondo et al. (14), using primers according to Huang et al. (10).

Specific IgM and IgG antibody immunoassays (EIAs). Serum samples at 1:200 dilution were tested for the presence of measles IgM antibody by the monoclonal-based capture enzyme immunoassay, described by Erdman et al. (7). The indirect EIA was used for detecting specific IgG in acute and convalescent serum dilutions $(7,11)$. Monoclonal antibodies were kindly supplied by Dr. William J. Bellini (CDC).

\section{RESULTS}

A comparison of the clinical and laboratory findings in typical and modified measles cases, as well as in other rash illnesses which were confused with measles, is recorded in Table 1. A measles etiology for the illnesses included in the study was confirmed in 07 of the 11 cases examined, 4 of them in young adults. A specific IgM test was positive in all (7/7) acute serum samples from measles cases. Reverse transcription PCR and virus isolation were both positive in 2 cases from whom peripheral blood lymphocytes and urine samples were obtained. IgG seroconversion in acute and convalescent serum pairs occurred in 1cases.

In the remaining 4 suspected measles cases, another etiology was found (Table 1). Two patients were diagnosed with exanthem subitum (roseola infantum), one with scarlet fever and one with Kawasaki disease. All these cases fulfilled the Health Ministry of Brazil clinical case definition criteria. Laboratory confirmation of exanthem subitum was done by "nested" PCR from peripheral blood lymphocytes collected from Patients 3 and 4. Group A beta-hemolytic streptococci were isolated from throat cultures of Patient 5. Patient 6, with Kawasaki disease, was negative in all performed diagnostic 
Table 1 Comparative clinical and laboratory findings in children and young adults with measles-like rash illness, São Paulo, Brazil, 1997

\begin{tabular}{|c|c|c|c|c|c|c|c|c|c|c|c|c|c|c|}
\hline \multirow[t]{2}{*}{ Patient } & \multirow[t]{2}{*}{ Age } & \multirow[t]{2}{*}{ Vaccination } & \multirow{2}{*}{$\begin{array}{l}\text { High } \\
\text { Fever }\end{array}$} & \multirow{2}{*}{$\begin{array}{c}\text { Koplik } \\
\text { Spots }\end{array}$} & \multirow[b]{2}{*}{$\geq 3$ days } & \multirow{2}{*}{$\begin{array}{c}\text { Rash } \\
\text { Maculoapular }\end{array}$} & \multirow[b]{2}{*}{ Vesicular } & \multirow[t]{2}{*}{ Specimen } & \multirow[b]{2}{*}{ IgM detection* } & \multicolumn{3}{|c|}{ Laboratory Results } & \multirow[b]{2}{*}{ Nested PCR } & \multirow[t]{2}{*}{ Final Diagnosis } \\
\hline & & & & & & & & & & Seroconversion* & RT-PCR & Isolation & & \\
\hline \multirow[t]{2}{*}{1} & $4 \mathrm{y}$ & Yes & + & - & + & + & - & Serum & + & & & & & Typical Measles \\
\hline & & & & & & & & Urine & & & + & Measles 97-1 & & \\
\hline 2 & $2 \mathrm{mo}$ & No & + & - & + & + & - & Serum & + & & & & & Typical Measles \\
\hline \multirow[t]{2}{*}{3} & $4 \mathrm{mo}$ & No & + & - & + & + & - & Serum & - & & & & & Exanthem Subitum \\
\hline & & & & & & & & PBL & & & & & HHV-6 & \\
\hline \multirow[t]{2}{*}{4} & $2 \mathrm{y}$ & No & + & - & + & + & - & Serum & - & & & & & Exanthem Subitum \\
\hline & & & & & & & & PBL & & & & & HHV-6 & \\
\hline \multirow[t]{2}{*}{5} & $4 \mathrm{mo}$ & No & + & - & + & + & - & Serum & - & & & & & Scarlet Fever \\
\hline & & & & & & & & Throat & & & & Streptococci & & \\
\hline 6 & $2 \mathrm{y}$ & Yes & + & - & + & + & - & Serum & - & - & & & & Kawasaki Disease \\
\hline 7 & $32 \mathrm{y}$ & No & + & + & + & + & - & Serum & + & & & & & Typical Measles \\
\hline 8 & $23 \mathrm{y}$ & Yes & + & - & - & + & - & Serum & + & + & & & & Modified Measles \\
\hline 9 & $30 \mathrm{y}$ & Yes & - & - & + & + & - & Serum & - & + & & & & Modified Measles \\
\hline 11 & $24 \mathrm{y}$ & No & + & + & + & + & - & Serum & + & & & & & Typical Measles \\
\hline \multirow[t]{3}{*}{12} & $6 \mathrm{mo}$ & Yes & + & - & + & + & - & Serum & + & & & & & Typical Measles \\
\hline & & & & & & & & PBL & & & + & Measles 97-2 & & \\
\hline & & & & & & & & Urine & & & + & Measles 97-2 & & \\
\hline
\end{tabular}

* Measles specific antibody tests

HHV-6: Human Herpesvirus 6

PBL: Peripheral blood lymphocytes

Group A beta-hemolytic streptoccoci were isolated from throat specimens seeded on blood agar cultures

Kawasaki Disease was diagnosed by platelet count, sedimentation rate and echocardiographic changes 
tests, having elevated platelet counts, an elevated erythrocyte sedimentation rate and a pericardial effusion on echocardiogram.

Clinical presentations varied in the confirmed measles cases. High fever $\left(>38.2^{\circ} \mathrm{C}\right)$ was documented in all cases, Koplik's spots were present in only 2 patients at examination. All patients had at least one of the following symptoms: cough, coryza and conjunctivitis. Four patients had no fever and/or rash for 3 days or more. One of them was atypical in that he was young adult (Patient 8) who had an immunization history when he was 7 months old (Table 1).

\section{DISCUSSION}

The successful elimination of measles will be facilitated by the timely detection of and response to measles epidemics. Detection of outbreaks depends on the accurate diagnosis of a rash illness. Inaccurate diagnosis of such illness may result in disease spread, as well inefficient use of limited resources. The clinical case definition of measles used by Health Ministry of Brazil relies on the presence of fever, rash, and at least one of the following symptoms: cough, coriza and conjunctivitis. The accuracy of this definition, however, may vary with the incidence of measles, the incidence of other rash illnesses and patient characteristics such as age, immunization history, and race $(6,15)$. Some of the other rash and fever illnesses which may be confused with measles include common childhood exanthems, such as rubella, scarlet fever, erythema infecciosum, meningococcemia, Kawasaki disease, toxic shock syndrome and dengue fever $(5,8)$. More recently, exanthem subitum (roseola infantum) was also included (4).

Vaccine-modified measles lead to under-reporting of measles cases and result in overestimation of vaccine efficiency in highly vaccinated populations. So, the laboratory will play a critical role in monitoring the success of measles control strategies by confirming typical and modified measles cases. It was shown that $16 \%$ of vaccinated patients with measles had IgM-negative serology or failed to meet the clinical case definition (6). Consequently, this fraction of measles cases will not be detected when only IgM-serology is used for laboratory confirmation. IgM-negative cases have to be confirmed by measles antigen or RNA-detection, or by seroconversion of paired serum samples.

In the present study we found one young adult with modified measles, (Table 1). This case (Patient 8) had an IgMpositive antibody and is defined as a "primary vaccine failure". "Primary and secondary vaccine failures" were estimated to involve, together, 13 to $30 \%$ of all vaccinated individuals and are held responsible for outbreaks in children and young adults in populations with high vaccine coverage $(6,23,24)$.

In our study, 4 patients presenting with a measleslike rash were ultimately diagnosed as Human Herpesvirus 6 infections (exanthem subitum), scarlet fever and Kawasaki disease. These cases illustrate the difficulties that can arise when trying to differentiate measles and clinically similar illnesses such as those diagnosed here. Clearly clinical features alone may not be for sufficient to establishing an accurate diagnosis in the post-vaccine era and, therefore, a laboratory based surveillance is essential for the success of measles control.

Reverse transcription PCR was successfully applied in our laboratory for the detection of measles RNA, present in peripheral blood lymphocytes, and urine sediment collected from two patients from whom these samples were available, using primers targeted to highly conserved regions of the $\mathrm{N}$ gene. While this PCR has been used in some research laboratories, it is not yet widely used for diagnostic purposes (9). Successful RT-PCR amplification of measles virus RNA from urine samples allows rapid diagnosis of a large number of infected individuals by noninvasive means. Collection of urine specimens is more readily and conveniently accessible than serum or nasopharingeal aspirates and could be done in the absence of a medical professional. RT-PCR has shown increased sensitivity compared with antigen detection by an immunofluorescence technique that was used in earlier studies, detecting measles RNA in urine specimens from vaccinated children as late as 14 days after immunization(21)

The recrudesence of measles in Brazil in 1997 has prompted a renewed interest in measles diagnostics. Although our study deals with a small number of patients, it demonstrates the continuing need for laboratory support.

\section{ACKNOWLEDGEMENTS}

This study was possible thanks to Fundação de Amparo à Pesquisa do Estado de São Paulo -FAPESP- São Paulo, SP, Brasil. We would also like to express our gratitude to Dr. William J. Bellini and to Dr. Paul A. Rota, Centers for Disease Control and Prevention (CDC), Atlanta, GA, USA, and to David Beckman, Chemicon International, Inc., Temecula, Calif., USA, for the support of specific reagents.

\section{RESUMO}

\section{Avaliação clínica e laboratorial de exantema semelhante ao sarampo em crianças e jovens adultos}

Apresenta-se um estudo sobre a avaliação clínica e laboratorial de crianças e adultos jovens com exantema semelhante ao sarampo, durante a ocorrência do surto epidêmico de sarampo na região metropolitana da Grande São Paulo no final de 1996 que se alastrou por todo o país durante o ano de 1997. O diagnóstico laboratorial de sarampo foi firmado em 7 dos 11 pacientes examinados, por detecção direta de IgM específico em amostras de soro da fase aguda da doença, por soroconversão de IgG em um par de amostras da fase aguda e 
convalescente, pelo isolamento do vírus em culturas de linhagem B95a e pela detecção do RNA viral por PCR em linfócitos do sangue periférico e na urina. O quadro clínico apresentado pelos pacientes nem sempre correspondeu à forma clássica do sarampo. Um jovem adulto, que havia sido vacinado contra o sarampo, apresentou um quadro clínico modificado. Os 4 casos restantes foram negativos em todas as provas laboratoriais para o sarampo, tendo diagnóstico final de exantema súbito (2 casos), escarlatina e Doença de Kawasaki. $\mathrm{O}$ presente estudo reforça o ponto de vista de que os sinais e sintomas clínicos são geralmente insuficientes para estabelecer um diagnóstico preciso de sarampo na era pós-vacinal, sendo indispensável um sistema de vigilância baseado em resultados laboratoriais que confirmam todos os casos suspeitos, inclusive os casos de sarampo com sorologia IgM-negativa

Palavras-chave: sarampo, avaliação clínica, investigação laboratorial, reação de polimerização em cadeia, isolamento viral, ensaio enzimático.

\section{REFERENCES}

1. Atkinson, D. E.; Orenstein, W. A. The ressurgence of measles in the United States, 1989-1990. Ann. Rev. Med., 43: 451-63, 1992.

2. Bellini, W. J.; Rota, J. S.; Rota, P. Virology of measles virus. J. Infect. Dis., 170 (suppl.1): S15-S23, 1994.

3. Bellini, W. J.; Rota, P. A. Measles (rubeola) virus. In: Lennette E. H. et al. Diagnostic Procedures for Viral, Rickettsial, and Chlamydial Infections, $7^{\text {th }}$ ed. Washington D. C. American Public Health Association, 1995. P. 447-54.

4. Black, J. B.; Durigon, E., Kite-Powell, K.; de Souza, L.; Curli, S. P.; Afonso, A.M. ; Theobaldo, M.; Pellett, P. E. Seroconversion to human herpesvirus 6 and human herpesvirus 7 among Brazilian children with clinical diagnosis of measles or rubella. Clin. Infect. Dis., 23: 1156-8, 1996.

5. Brown, D. W.; Ramsay, M. E.; Richards, A. F.; Miller, E. Salivary diagnosis of measles: a study of notified cases in the United Kingdom, 1991-3. Br. Med. J., 308: 1015-17, 1994.

6. Edmonson, M. B.; Addiss, D. G.; Mcpherson, J. T.; Berg, J. L.; Circo, S. R.; Davis, J. P.. Mild measles and secondary vaccine failure during a sustained outbreak in a highly vaccinated population. JAMA., 263: 2467-70, 1990.

7. Erdman, D. D. Anderson, L. J.; Adams, D. R.; Stewart, J. A.; Markowitz, L. E.; Bellini, W J. Evaluation of monoclonal antibody-based capture enzyme immunoassays for detection of specific antibodies to measles virus, J. Clin. Microbiol., 29: 1466-71, 1991.
8. Frieden, I. J.; Resnick, S. D. Childhood exanthems, old and new. Peds. Clin. N. Amer, 38: 859-87, 1991.

9. Griffin, D. E.; Bellini, W. J. Measles virus. In: Fields, B. N. et al. Fields Virology, $3^{\text {rd }}$ ed. Philadelphia, Lippincott-Raven Publishers, 1996. P. $1267-1312$

10. Huang, L. M.; Kuo, P. F.; Lee, C. Y.; Chen, J. Y.; Liu, M. Y.; Yang, C. S. Detection of human herpesvirus 6 DNA by polymerase chain reaction in serum and plasma. J. Med. Virol., 165: 7-10, 1992.

11. Hummel, K. B.; Erdman, D.D.; Heath, J.L.; Bellini, W.J. Baculovírus expression of the nucleoprotein gene of measles virus and utility of the recombinant protein in diagnostic enzyme immunoassay. J. Clin. Microbiol; 30: 2874-80, 1992.

12. Hussey, G. D.; Clements, C. J. Clinical problems in measles management. Ann. Trop. Paediat., 16: 307-17, 1996.

13. Kobune, F.; Sakata, H. ; Sugiura, A. Marmoset lymphoblastoid cells as a sensitive host for isolation of measles virus. J. Virol., 64: 700-5, 1990.

14. Kondo, K..; Hayakawa, Y.; Mor, H.; Sato, S.; Kondo, T.; Takahashi, K,. Minamishima, Y.; Takahashi, M.; Yamanishi, K.. Detection by polymerase chain reaction amplification of human herpesvirus 6 DNA in peripheral blood of patients with exanthem subitum. J. Clin. Microbiol., 28: 970-4, 1990.

15. Makhene, M. K.; Diaz, P, S. Clinical presentations and complications of suspected measles in hospitalized children. Pediatr. Inf. Dis. J., 12: 836-40, 1993.

16. Minnich, L. L.; Goodenough, F.; Ray, C. G. Use of immunofluorescence to identify measles virus infections. J. Clin. Microbiol., 29: 1148-50, 1991.

17. Pan American Health Organization. Measles elimination by 2000. Epi Newsletter, 16: 1-2, 1994.

18. Pan American Health Organization. Measles surveillance in the Americas. Special program for vaccines and immunization. Wkly. Bull., 3 (22), 1997.

19. Quadros, C. A. De; Hersh, B. S.; Nogueira, A. C.; Carrasco, P.A.; Da Silveira, C. M. Measles elimination in the Americas: evolving strategies. JAMA., 275: 224-9, 1996.

20. Rima, B. K. ; Earle, J. A.; Yeo, R. P.; Herlihy, L.; Baczko, K.; ter Meulen, V.; Carabana, J.; Caballero, M.; Celma, M. L.; FernandezMunoz, R. Temporal and geographical distribution of measles virus genotypes. J. Gen. Virol., 76: 1173-80, 1995.

21. Rota, P. A.; Khan, A. S.; Durigon, E.; Juran, T.; Villarmarzo, Y. S.; Bellini, W J. Detection of measles virus nucleic acid in urine specimens from vaccine recipients. J. Clin. Microbiol., 33: 2485-8, 1995.

22. Smith, E. A. ; Foster, S. O. Measles in areas of malnutrition. $J$. Nigeria Med. Assoc., 7: 16-18, 1970.

23. Stewien, K.. E.; Stewien, K. E.; Barbosa, V.; de Lima, O. S. ; Osiro, K. The influence of maternally derived antibody on the efficacy of further attenuated measles vaccine. Infection, 8: 207-210, 1978

24. Waldman, E. A. ; Camargo, M. C. C. Current status of measles in Brazil, 1980-1995. Virus Reviews \& Research, 1: 67-74, 1996.

25. World Health Organization. Expanded program on immunization accelerated measles strategies. Wkly. Epidemiol. Rec., 69: 229-34, 1994. 